\title{
An Analysis of Students' Critical Thinking Skills for the Topic of Biotechnology of Senior High Schools in Labuhanbatu Utara Regency
}

\author{
Era Damayanti Tambunan ${ }^{1)}$, Martina Restuati ${ }^{2)}$, Melva Silitonga ${ }^{2)}$ \\ ${ }^{1}$ Student of Postgraduate Program of Biology Education, UniversitasNegeri Medan, Indonesia \\ ${ }^{2}$ Lecturer of Postgraduate Program of Biology Education, UniversitasNegeri Medan, Indonesia \\ ${ }^{2}$ Lecturer of Postgraduate Program of Biology Education, UniversitasNegeri Medan, Indonesia \\ e-mail: eradamayantitambunan@gmail.com
}

\begin{abstract}
The aims of this study were to find out: (1) the levels of students' critical thinking skills based on school location, gender, and indicators; and (2) the levels of students' critical thinking accomplishments. This present study employed a descriptive research with a quantitative approach. The samples were the eleventh grade students of Science Program. All data were collected by using the instruments of critical thinking tests in the form of students' essay tests. The data was subsequently analyzed by the descriptive statistics and Spearman Test. The results showed that: (1) the levels of students' critical thinking skills for the topic of Biotechnology at Grade XII of Senior High Schools in Labuhanbatu Utara were moderate (70.25); (2) the levels of students' critical thinking skills based on school location near town/urban were high $\mathbf{( 7 3 . 1 6 )}$, meanwhile their critical thinking skills near village/suburban were moderate (66.53); (3) the levels of critical thinking skills based on gender for male were high (71.13), meanwhile for female were moderate (69.41); (4) the levels of students' critical thinking skills based on indicators that were included in high category were the indicators of analyzing data (75.08), evaluating (73.94), generalizing (72.49), having a similarity and difference (71.46), making opinions (71.22), while the indicators that were included in moderate category were the indicators of making a conclusion (70.58), interpreting (67.12), giving alternatives (65.79), identifying problems $(64.46)$, and formulating problems (61.58). Finally, (5) the levels of students' critical thinking accomplishments were good $(62.12 \%)$.
\end{abstract}

\section{Keywords—critical thinking skills, biotechnology}

\section{INTRODUCTION}

Learning is basically an effort to direct students into the learning process so that they can obtain learning goals in accordance with what is expected. Learning should pay attention to the condition of individual students because they will learn. Students have properties that are different from each other, each uniqueness that is not the same as others. Therefore, learning should pay attention to individual differences in students, so that learning can really change the condition of students from those who do not know to know, from those who do not understand to understand and from those who behave poorly to be good.

Science education has an important role in preparing students to enter the world of life. Science is a product and process. Science products include facts, concepts, principles, theory and law. While the science process includes ways to obtain, develop and apply knowledge that includes ways of working, ways of thinking, ways of solving problems, and ways of behaving. Therefore, science is formulated systematically, mainly based on experimental and induction observations.

One part of modern biotechnology is material that is difficult for students to understand because the material part is abstract. Therefore, the curriculum 2013 has an attitude assessment as an important thing to develop. In addition, the ability to think critically in biotechnology material is very good for analysis because the material is material that is very difficult for students to understand. The alternative to be able to improve students' thinking ability is the presence of teaching skills that teachers do in the form of variation skills in displaying interesting and fun learning.

Student learning activities using all sensory tools are learning that makes students easier to understand learning. Learning is expected to be student-centered where students are active in the classroom while the teacher becomes a facilitator, not full authority over the class. The learning process is expected to be able to develop students' abilities like an expert in conducting research activities observing, asking, trying, reasoning, and communicating. Biotechnology materials can be studied and practiced directly to find out these lessons, such as making tempeh in the subject of conventional biotechnology. With the practicum in biotechnology is a learning that provides a good assessment because it can improve students' skills or skills. According to [1], assessment requires teachers to collect information as complete as possible for the purpose of making teaching decisions, so that expected decisions are taken on target.

According to [2] that developing critical thinking skills in Indonesia has several constraints, one of which is the dominance of the teacher in the learning process and does not provide access to students to develop independently through discovery and thought processes. Real conditions so far that students lack attention among educators. This can be seen from the attention of some teachers who tend to pay attention to the class as a whole, not individuals or small groups, so that individual differences get less attention. Learning that does not pay attention to individual student differences and is based on the teacher's wishes, will be difficult to be able to deliver students towards the achievement of learning goals. This condition is what generally occurs in conventional learning. 
The consequences of learning like this that cause a real gap between students who are smart and less intelligent in achieving learning goals. Conditions like this also result in not obtaining mastery in learning, where the categories obtained are poor. This proves the failure in the learning process in schools that are not in accordance with the learning objectives to be achieved.

Based on observations in class XII SMA in North Labuhanbatu District that the level of student learning completeness is still low in understanding the learning material about Biotechnology with a KKM score of 70 that has been determined in each school. Where the overall completeness of the overall school obtained by students is only $40.71 \%$. The details of student learning completeness in each school year 2015/2016 that in SMAN 1 Kualuh Selatan amounted to $45.71 \%$, SMAN 1 AekNatas amounted to $52.86 \%$, SMAN 1 KualuhLeidong by $41.43 \%$, SMAN 1 KualuhHilir by 34 , 29\%, SMASKesumaBangsa Londut amounted to $44.29 \%$, SMASMuhammadiyah 9 AekKanopan amounted to $38.57 \%$, SMAS DI Panjaitan was $32.86 \%$, and SMASPelitaAekKanopan was $35.71 \%$. Based on the average value of the completeness of the learning it can be stated that the value is categorized as not good. This can be seen when the learning process takes place in the classroom where students' curiosity in seeking information is still very low, lacking in dissent between classmates and lack of good cooperation. This is evident from students who only receive information from the teacher. So that students' understanding of a material that is learned is still weak and difficult to understand. Biotechnology materials delivered by using lecture learning alone will not generate students' cognitive thinking skills because students are forced to be able to receive information from the teacher in other words this learning process is only teacher-centered. Biotechnology is a material that is difficult for students to understand because the material must be carried out by direct learning applications so that students more easily understand and create goods and services produced from living things as an indicator of the material. If this is not made a change with the use of direct or varied learning models that support it will affect the level of critical thinking skills and scientific attitudes of students in learning so that it becomes less optimal. This was stated by [3] that the low quality of education was due to the low ability of students to think critically. In general, students are directed to memorize and receive as much information as possible, so that students are able to theoretically but not be able to apply it. As a result, critical thinking skills become frozen, and even become difficult to develop so that students' scientific attitudes are less optimal.

The low ability to think critically results in students not understanding the material used so learning only by memorization can cause boredom. It also has an impact on students' thinking to be less systematic so that students find it difficult to understand abstract Biotechnology concepts, which results in a low scientific attitude of students.

Based on the results of interviews conducted with the Biology teacher of class XII IPA of the State High School
Labuhanbatu Utara Regency, it is known that Biotechnology material is one of the material that is difficult for students to understand at school. This is considered difficult because the material is abstract in the modern Biotechnology section. Students have never seen firsthand the processes that occur in the learning of modern biotechnology such as tissue culture and genetic engineering. Indirect learning can make students difficult to understand the material presented by the Biology teacher at the school.

The selection of a varied learning model on Biotechnology material is expected to be an alternative in changing students' interesting learning conditions to prefer the material, so that it is motivated and active and gives a good impression in participating in Biotechnology lessons. The use of learning models conducted by teachers must be able to invite students to optimize all the potential possessed by students. Because students are directed to find new things in the material in a varied learning model so it is hoped that this method can improve students' critical thinking skills.

\section{LITERATURE REVIEW}

Thinking is a mental process of someone who is more than just remembering and comprehensing. When we think propositionally, the sequence of thoughts is organized (organized), the mind is organized by long-term memory. The sequence of thoughts can occur in the form of arguments in which one proposition is the same as drawing a conclusion [4].

According to [5] critical thinking is reflective and productive thinking, and involves evaluating evidence. Critical thinking is empowering cognitive skills or models in determining goals [6]. Critical thinking process is passed after setting goals, considering, and referring directly to thinking goals that need to be developed in order to solve problems, form conclusions, gather various possibilities, and make decisions when using all these skills effectively in the right context and type. Critical thinking is also an activity of evaluating and considering the conclusions to be taken when determining several supporting factors for making decisions. Critical thinking is also commonly called directed thinking, because thinking directly to the focus will be addressed.

\section{RESEARCH METHOD}

\subsection{Location and Time of the Study}

The study was carried out in senior high schools throughout Labuhanbatu Utara Regency, which included SMA Negeri 1Kualuh Selatan, SMA Negeri 1 Aek Natas, SMA Negeri 1 Kualuh Leidong, SMA Negeri 1 Kualuh Hilir, SMA Swasta Kesuma Bangsa Londut, SMA Swasta Muhammadiyah 9 Aek Kanopan, SMA Swasta D.I. Panjaitan, and SMA Swasta Pelita Aek Kanopan. The study was held from April to June 2017.

\subsection{Population and Sample of the Study}

The population in this study were all high school class XII in North Labuhan District except superior class. Data of 
students who become population and sample in this study are presented in Table 1.

TABLE 1.Research Population and Sample

\begin{tabular}{|c|c|c|c|}
\hline Name of School & Location & Population & Sample \\
\hline SMAN 1 Kualuh & Urban & 4 classes & 1 class of \\
\hline Selatan & Area & $\begin{array}{c}\text { (124 } \\
\text { students) }\end{array}$ & $\begin{array}{l}\text { XII IPA } 3 \\
\quad(37 \\
\text { students })\end{array}$ \\
\hline SMAN 1 & Urban & 5 classes & 1 class of \\
\hline AekNatas & Area & $\begin{array}{c}\text { (138 } \\
\text { students) }\end{array}$ & $\begin{array}{l}\text { XII IPA } 3 \\
\quad(39 \\
\text { students })\end{array}$ \\
\hline $\begin{array}{l}\text { SMAN } 1 \\
\text { KualuhLeidong }\end{array}$ & $\begin{array}{c}\text { Suburban } \\
\text { Area }\end{array}$ & $\begin{array}{c}3 \text { classes (88 } \\
\text { students) }\end{array}$ & $\begin{array}{c}1 \text { class of } \\
\text { XII IPA } 2 \\
(34 \\
\text { students })\end{array}$ \\
\hline $\begin{array}{l}\text { SMAN } 1 \\
\text { KualuhHilir }\end{array}$ & $\begin{array}{c}\text { Suburban } \\
\text { Area }\end{array}$ & $\begin{array}{c}2 \text { classes (62 } \\
\text { students) }\end{array}$ & $\begin{array}{c}1 \text { class of } \\
\text { XII IPA } 2 \\
(38 \\
\text { students })\end{array}$ \\
\hline $\begin{array}{l}\text { SMAS } \\
\text { KesumaBangsaL } \\
\text { ondut }\end{array}$ & $\begin{array}{l}\text { Urban } \\
\text { Area }\end{array}$ & $\begin{array}{c}2 \text { classes (72 } \\
\text { students) }\end{array}$ & $\begin{array}{c}1 \text { class of } \\
\text { XII IPA } 1 \\
(36 \\
\text { students })\end{array}$ \\
\hline $\begin{array}{l}\text { SMAS } \\
\text { Muhammadiyah } \\
9 \text { AekKanopan }\end{array}$ & $\begin{array}{l}\text { Urban } \\
\text { Area }\end{array}$ & $\begin{array}{l}2 \text { classes (80 } \\
\text { students) }\end{array}$ & $\begin{array}{c}1 \text { class of } \\
\text { XII IPA } 1 \\
(36 \\
\text { students) }\end{array}$ \\
\hline $\begin{array}{l}\text { SMAS D.I. } \\
\text { Panjaitan }\end{array}$ & $\begin{array}{c}\text { Suburban } \\
\text { Area }\end{array}$ & $\begin{array}{l}1 \text { class }(21 \\
\text { students) }\end{array}$ & $\begin{array}{c}1 \text { class of } \\
\text { XII IPA } 1 \\
(21 \\
\text { students })\end{array}$ \\
\hline $\begin{array}{l}\text { SMAS } \\
\text { PelitaAekKanop } \\
\text { an }\end{array}$ & $\begin{array}{c}\text { Suburban } \\
\text { Area }\end{array}$ & $\begin{array}{l}1 \text { class (23 } \\
\text { students) }\end{array}$ & $\begin{array}{c}1 \text { class of } \\
\text { XII IPA } 1 \\
(23 \\
\text { students })\end{array}$ \\
\hline Total & & 608 students & $\begin{array}{c}264 \\
\text { students }\end{array}$ \\
\hline
\end{tabular}

\subsection{Type and Design of the Research}

This type of research is descriptive research with a quantitative approach. This research method is used to investigate the level of students' critical thinking skills in learning Biotechnology material in the twelfth grade of senior high school students.

\subsection{Instruments of Data Collection}

Data collection techniques were carried out by using the instrument of critical thinking skill tests in order to obtain valid and appropriate data. After validation it was obtained 10 questions about the form of the description with actual, factual, and contextual problems. The selection of the description test form aims to reveal the ability to think critically, which is prepared by the researcher by referring to the indicators proposed by [7]. The indicators used are: (1) inferential (ability to identify problems); (2) assumptions (ability to respond); (3) deduction (ability to do reasoning logically); (4) interpretation (ability to conduct induction/oral communication); and (5) evaluation (ability to conduct assessments).

\subsection{Technique of Data Analysis}

The critical thinking skill test instrument that has been compiled was tested to determine the validity, reliability, power of difference, and level of difficulty. Before being used as a data collection tool, instruments in the form of critical thinking skills tests that have been compiled were validated by experts so that the instrument could be used in a good and valid research.

The data obtained were then analyzed quantitatively descriptive by describing the respondent's answers related in this study regarding students' critical thinking skills.

\section{RESULTS AND DISCUSSION}

\subsection{Results}

Based on the results of data analysis obtained the level of students' critical thinking skills based on the school location, gender, and indicators and then obtained the level of completeness of students' critical thinking skills of Biotechnology in class XII of Senior High Schools in Labuhanbatu Utara as follows:

\subsubsection{Level of Students' Critical Thinking Skillsfor Biotechnologyin class XII of Senior High Schools in Labuhanbatu Utara}

Based on the results of the research and analysis that has been done to determine the level of critical thinking skills of students in class XII of Senior High Schools in Labuhanbatu Utara, data from the total number of students as many as 264 people obtained an average value of 70.25 . The average value of students' critical thinking skills from each school can be seen in the Figure 1. 


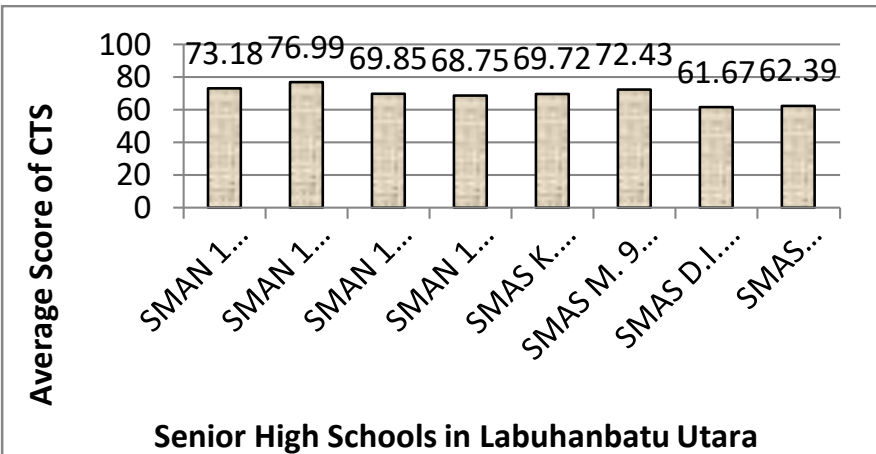

Fig1. Level of Students' Critical Thinking Skills from Each School in Labuhanbatu Utara Regency

4.1.2. Level of Students' Critical Thinking Skills for Biotechnology in Class XII ofSenior High Schools in Labuhanbatu Utara Regency Based on School Location

From the results of the research and analysis that has been done to determine the level of students' critical thinking skillsof the senior high schools in Labuhanbatu Utara based on school location in urban areas with the number of students as many as 148 people obtained an average value of 73.16 . While the location of the schools in suburban areas with the number of students as many as 116 people obtained an average value of 66.53. The average value of the level of students' critical thinking skills based on school location can be seen in Figure 2.

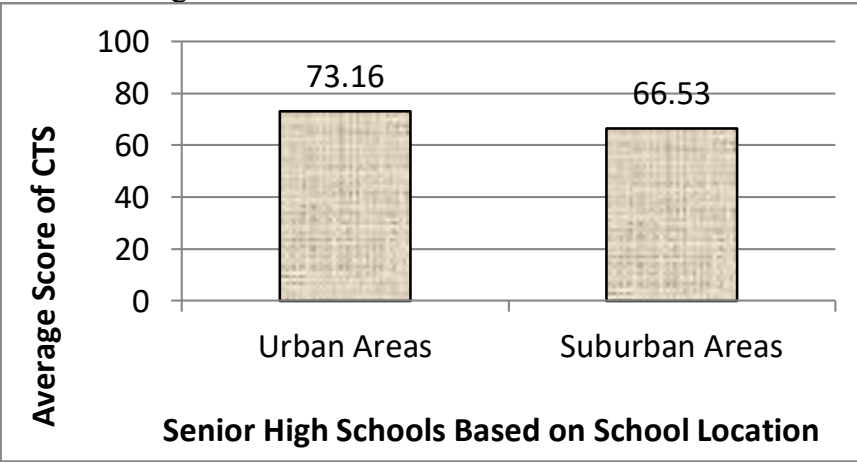

Fig2. Level of Students' Critical Thinking Skills in Labuhanbatu Utara Regency Based on School Location

4.1.3. The Level of Students' Critical Thinking Skills for Biotechnologyin Class XII of Senior High Schools in Labuhanbatu UtaraBased on Gender

From the results of the research and analysis that has been done to determine the level of students' critical thinking skills in Class XII of Senior High Schools in Labuhanbatu Utara based on gender for male students with a total of 128 obtained an average value of 71.13. While for female students with a total of 136, the average score was 69.41 . There was an average value of level of students' critical thinking skills based on gender can be seen in Figure 3.

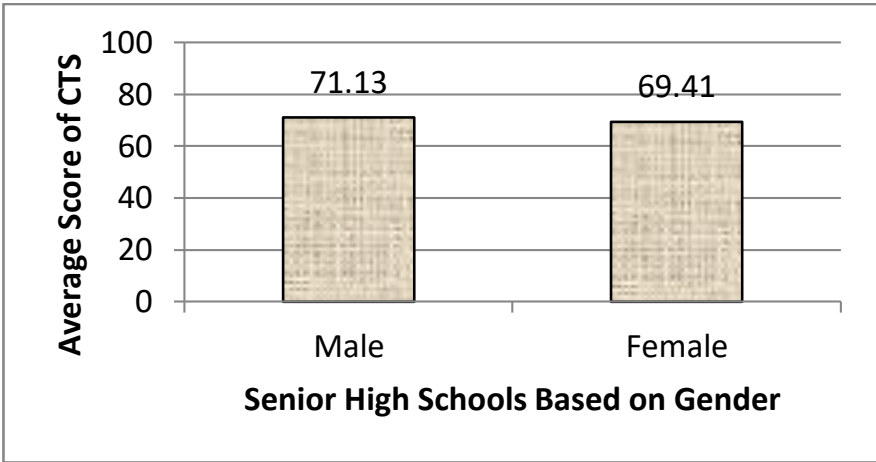

Fig3. Level of Students' Critical Thinking Skills in Labuhanbatu Utara Regency Based on Gender

4.1.4. Level of Students' Critical Thinking Skills for Biotechnology in Class XII of Senior High Schools in Labuhanbatu Utara Based on Indicators

From the results of the research and analysis that has been done to determine the level of students' critical thinking skills of Senior High Schools in Labuhanbatu Utara Regency with the number of students as many as 264 people based on indicators 1.1, indicator 1.2, indicators 2.1, indicators 2.2, indicators 3.1 , indicators 3.2 , indicators 4.1 , indicator 4.2 , indicator 5.1, and indicator 5.2 overall obtained an average score of 70.25 . The average value of students' critical thinking skills based on indicators can be seen in Figure 4.

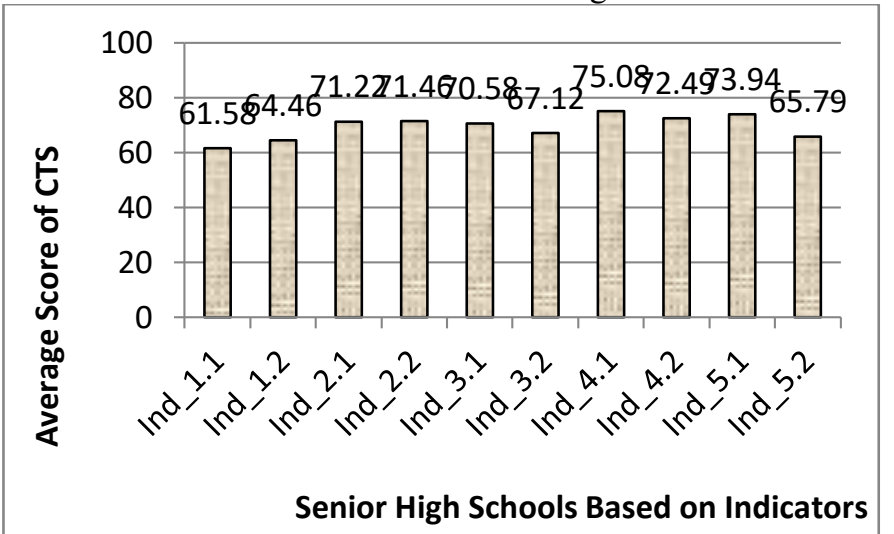

Fig 4. Level of Students' Critical Thinking Skills in Labuhanbatu Utara Regency Based on Indicators

4.1.5. The Level of Completeness of Students' Critical Thinking Skills for Biotechnology in Class XII of Senior High Schools in Labuhanbatu Utara

Based on the results of the study and analysis that has been done to determine the level of completeness of students' critical thinking skills of all Senior High Schools in Labuhanbatu Utara Regency data from the total number of students as many as 264 people. Complete students are students who are able to achieve the KKM values that have been established from each school, namely 70 . As for the percentage level of completeness of students' critical thinking skills can be seen in Figure 5. 


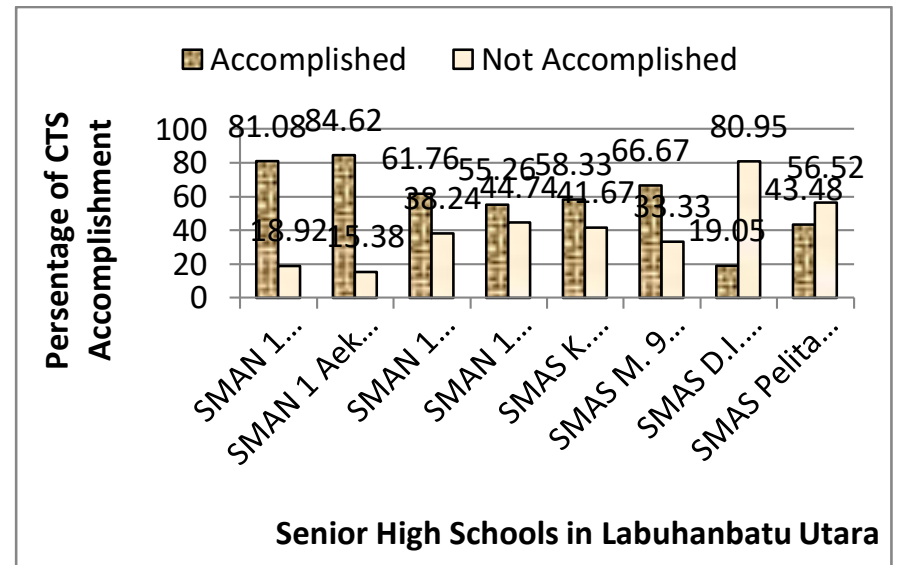

Fig 5. Level of Completeness of Students' Critical Thinking Skills from Each School in Labuhanbatu Utara Regency

Based on the level of completeness of students' critical thinking skills from each school, this can be accumulated throughout Labuhanbatu Utara Regency that the percentage of completeness can be seen in Figure 6.

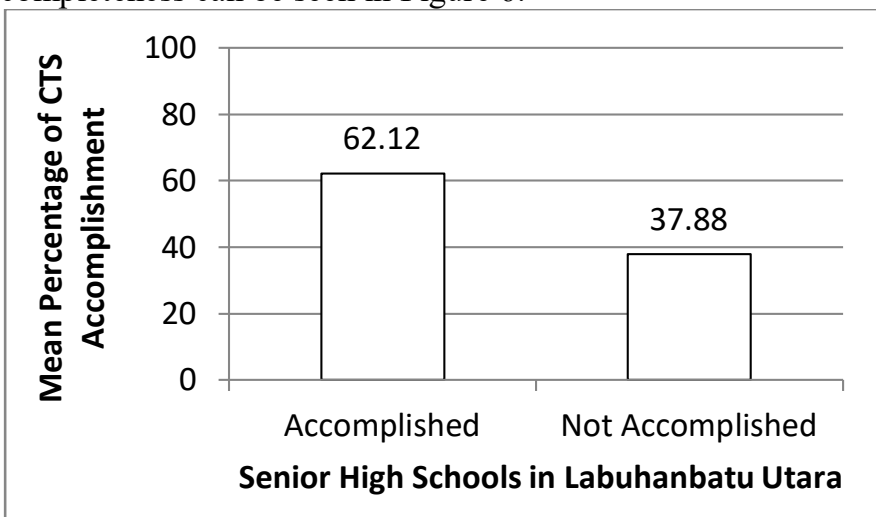

Fig 6. Completeness Level of Critical Thinking Skills of Senior High School Students in Labuhanbatu Utara Regency

\subsection{Discussion}

4.2.1. Level of Students' Critical Thinking Skills for Biotechnology in Class XII of Senior High Schools in Labuhanbatu Utara Regency

Based on the results of the study it was known that the level of students' critical thinking skills of all senior high schools in Labuhanbatu Utara Regency from 264 students obtained an average value of 70.25 which was included in the medium criteria [8]. Based on the acquisition of the level of students' critical thinking skills it was known that SMAN 1 AekNatas with an average value of 76.99, SMAN 1 Kualuh Selatan with an average value of 73.18, and SMAS Muhammadiah 9 AekKanopan with an average value of 72.43 has raised the level of students' critical thinking skills. This was because the three schools gained a higher level of critical thinking skills than the level of critical thinking skills in the high schools throughout Labura Regency. While SMAN 1 KualuhLeidong with an average value of 69.85, SMAS Kesuma BangsaLondutwith an average value of 69.72, SMAN 1 KualuhHilir with an average value of 68.75 , SMAS PelitaAekKanopan with a value an average of 62.39 , and SMAS DI Panjaitan with an average value of 61.67 has decreased the level of students'critical thinking skills. This was because the five schools obtained a level of critical thinking skills lower than the level of critical thinking skills in high schools throughout Labuhanbatu Utara Regency.

The acquisition of the students' level of critical thinking skills in Labuhanbatu Utara Regency includes the criteria of being, but there are also parts of critical thinking skills that students have not been able to master. The inability of students to understand the critical thinking skills part is indicated by the students' errors in answering the instruments of critical thinking skills that have been done. It can be seen that students do not fill in the reason for the answer correctly, so there are still many students who find it difficult to understand the topic of Biotechnology.

According to [9], the goal of critical thinking is to test an opinion or idea, including doing judgment or thinking based on the opinions put forward. The ability to think critically can encourage students to come up with new ideas about the problem. Students will be trained in how to select various opinions, so that they can distinguish which opinions are relevant and irrelevant. Developing students' critical thinking skills can help students make conclusions by considering data and facts that occur in the field.

There are factors that cause students not to fully understand the discussion of material that has been explained by the teacher at school or who interferes in the learning process. Most of the factors that dominate one of them is the lack of interest in student learning that can affect their understanding of the subject matter. According to [10] that interest is basically an acceptance of a relationship between oneself and something outside of oneself. Interest is very important in achieving achievement, position, or career. It will not be possible for people who are not interested in a job to finish the job properly.

The students in the high schools throughout Labuhanbatu Utara Regency feel that they have less interest in learning with Biotechnology material. Students consider the material will not relate directly to their lives and not many are interested in becoming a scientist who will practice the theory of biotechnology in the laboratory. Therefore, the teacher's strategy in explaining Biotechnology material related to the lives of everyday students aims to build interest student learning in a way the teacher must create learning with a pleasant atmosphere and full of tranquility, with the presence of a pleasant learning atmosphere, the student's desire to continue learning is created.

There are five schools that are below the average value of critical thinking skills in Labuhanbatu Utara Regency. According to [11] revealed that if students are accustomed to choosing and trying to process information that has been obtained, then students will be trained to solve problems, think 
critically, creatively, systematically and logically. The low level of students'critical thinking skills because students are not accustomed to following learning with activities that can train and improve students' critical thinking skills.

The low achievement of students' critical thinking skills can be a symptom of learning difficulties. According to [12] that the factors that cause student learning difficulties regarding biotechnology material are interest, motivation, and subject matter that is difficult for students, as well as other factors are psychological, health, family environment, and learning media that are less supportive so that students are less enthusiastic about learning well. This can affect critical thinking ability in understanding Biotechnology material.

Teacher learning methods that cause students' critical thinking skills are less than optimal is the lecture method, because this method is considered the most effective in explaining the material but makes students unable to develop their critical thinking skills. Using the lecture and question and answer method will not be able to develop students' critical thinking skills and students will be passive. This is also in line with the opinion of John Dewey (in [13]) who emphasizes that critical thinking is an active process, meaning to contrast a person's thinking process in receiving or obtaining information from other parties who tend to be passive. Therefore, the teacher must be able to create a learning model that is used by educators in the core activities of learning that are in accordance with the student-focused approach, the realm of learning, and the characteristics of subjects so that students become active so that they can build a more optimal way of thinking. The use of instructional media is needed so that students can more easily develop students' critical thinking skills in the presence of abstract biotechnology materials such as modern biotechnology. Limited learning media will affect the way of thinking and critical thinking students become less optimal.

In research regarding [14] logical thinking ability and concept understanding that abstract material such as modern biotechnology, teachers are advised to show learning media as a form of material visualization with the aim that students can more clearly imagine. This solution can create fun learning on biotechnology materials to improve students' critical thinking skills.

4.2.2. Level of Students' Critical Thinking Skills for Biotechnology in Class XII of Senior High Schools in Labuhanbatu Utara Based on School Locations

Based on the results of the study, it was known that the level of students'critical thinking ability of Senior High Schools in Labuhanbatu Utara Regency based on the location of schools in the urban areas, namely SMA 1 Kualuh Selatan, SMAN 1 AekNatas, SMAS K. Londut, and SMAS M. 9 AekKanopan from 148 students obtained an average score of 73.16 which is included in the high criteria [8]. Whereas the school location in the suburban areasare SMAN 1 KualuhLeidong, SMAN 1 KualuhHilir, SMAS D.I. Panjaitan, and SMAN PelitaAekKanopan from 116 students obtained an average score of 66.53 which was included in the criteria. From this value it was found that the level of students' critical thinking skills was higher in the school location in the urban areas compared to the school location in the suburban areas.

Learning facilities such as laboratories can support learning to be more enjoyable for students so that they can generate interest in their learning. Laboratories located in urban areas are quite complete and good, making it easier for students to understand and practice biotechnology theory compared to students in rural areas who have incomplete laboratories which reduce their interest in learning. Limitations of laboratory equipment in schools can affect students' critical thinking in understanding biotechnology material because it is not good in the application of material carried out in the laboratory.

With a complete laboratory in school, it will be able to help students to build good creativity to foster students' critical thinking skills. The advantages of practice according to Percival (in [15]) are: (1) In the delivery of materials, using direct and concrete activities and experiences; (2) More realistic and meaningful, because students work directly with real examples, (3) Students learn directly to apply the principles and steps of problem solving; and (4) Many provide opportunities for student involvement in learning situations. While the weaknesses are: (1) It takes longer than learning in theory; (2) For young students, their rational thinking skills are still limited; (3) Demanding independence, selfconfidence, habits acting as subjects in an environment that lacks role for students as subjects; (4) Difficulties in using the subjectivity factor, coming to conclusions too quickly and making too general generalizations from very limited experience.

The learning conditions in most schools have not been very supportive for the implementation of effective thinking skills learning. Some of the constraints include learning at school still focused on the teacher, and the focus of education in schools is more on just memorizing knowledge. The ability to think critically is actually a person's ability that can be learned and taught, both in school and independent learning. Therefore, complete facilities and good cooperation between teachers, students, principals, and local government are needed to create a more enjoyable learning environment. Paying attention to the needs of schools both in the urban and in the suburban areas.

Learning media in the form of animation is very supportive in the learning process to enable students to understand abstract lessons in modern biotechnology. In addition, the right learning model or approach is also very good to improve students' critical thinking skills, one of which is by applying scientific approach-based learning. This is in line with the research by [16] which concluded that there is a significant influence on the use of scientific approach based learning on critical thinking skills of grade X science students of Panjura High School Malang. Therefore, learning both in the city and in the villages the teachers must be able to apply a scientific approach to improve students' critical thinking skills. 
4.2.3. The Level of Students' Critical Thinking Skills for Biotechnology of Senior High Schools in Labuhanbatu UtaraBased on Gender

Based on the results of the study note that the level of students' critical thinking skills of Senior High Schools in Labuhanbatu Utara regency based on gender in male of 128 students obtained an average value of 71.13 which is included in the high criteria [8]. Whereas for female of 136 students, the average score was 69.41 which was included in the medium criteria. From these values it was found that the level of students' critical thinking skills was higher in male than in female.

The level of a person's critical thinking skills is strongly influenced by his learning experience. That is, if during the learning process that has been experienced by someone is often stimulated to do critical thinking activities, then it will have a good profile of critical thinking skills development. Based on the results of the analysis it was found that men have a higher critical thinking way than women which means that men have more stimulated experiences with critical thinking activities in everyday life.

According to Ennis (in [17]) states that critical thinking is a process of reflective thinking that focuses on deciding what is believed to be done. Experience and evaluation are the main components in improving critical thinking skills. Experience, both events and knowledge become the capital of selfevaluation in reflective thinking. From the evaluation, a belief emerged, both old beliefs and beliefs to be made. The level of critical thinking ability between male and femalevaries, in this study it turns out that male have more experience in their dayto-day thinking in critical thinking than female.

4.2.4. Level of Students' Critical Thinking Skills for Biotechnology in Class XII of Senior High Schools in Labuhanbatu Utara Based on Indicators

The critical thinking ability dimension consists of several indicators so that indicators are considered to be more specific. Achievement indicators on a study to develop students' critical thinking skills can be used as a measure of the extent of critical thinking ability of students to understand the basic materials.Based on the results of survey revealed the levels of students' critical thinking skills of Senior High Schools of 264 students based on indicators obtained the highest average value to the lowest starting from the indicator analyzing data 75.08, evaluation 73.94, generalization 72.49, equations and differences 71.46, argumentation 71.22 and the medium criteria was adrawing 70.58 conclusions, interpretation 67.12, giving alternative 65.79, identifying the problem 64.46, formulating the problem 61.58 .

Acquisition on indicator 4.1 as acquisition on high criteria indicated that students are generally able to analyze data well in accordance with indicators on the dimensions of students' critical thinking skills. Furthermore in indicator 5.1 showed that students are generally able to evaluate based on facts well, indicator 4.2 showed that students generally able to make generalizations well, indicator 2.2 showed that students are generally able to show similarities and differences well, indicator 2.1 showed that students are generally able to give good arguments. While the acquisition in indicator 3.1 as an acquisition on the medium criteria with good categories showed that students are generally able to draw conclusions logically well. Furthermore in indicator 3.2 showed that students are generally able to interpret well, indicator 5.2 showed that students are generally able to provide other alternatives well, indicator 1.2 showed that students are generally able to identify problems well, and indicator 1.1 showed that students are generally able formulate questions that direct investigations well in accordance with indicators on the dimensions of students' critical thinking skills.

The ability to think critically is one that is expected to be mastered by students in the learning process. The effectiveness of critical thinking requires skills that will help determine the accuracy of information and will help in recognizing illogical arguments [18]. Students must be guided by expertise in interpreting, analyzing, inference, evaluation, explaining, and self-assessment as a means of exploring critical thinking skills $[19$.

The benefits of biotechnology are very high for life, because biotechnology has high potential to solve various problems of the modern world as it is currently decorated with technological sophistication. However, on the other hand biotechnology still has a problem especially related to ethics [20]. Therefore, with the improvement of students' critical thinking skills in biotechnology material it is very important to do. Discussing biotechnology is very interesting because it relates to the ethics of life. With the advantages and disadvantages of biotechnology, it is expected that the next generation can think more critically to develop biotechnology by continuing to pay attention to the ethics of life.

According to [21] that empowering thinking skills during science learning is very important. Through science learning students will have the skills to face and solve problems in their lives in the future. Therefore, intelligent thinking is needed to formulate scientific learning strategies in order to empower students' thinking skills optimally.

4.2.5. Completeness Level of Students' Critical Thinking Skills for Biotechnology in Class XII of Senior High Schools in Labuhanbatu Utara

Based on the results of the study it was known that the level of completeness of students' critical thinking skills of Senior High Schools in Labuhanbatu UtaraRegency of 264 students who were declared complete were students who were able to achieve the KKM scores that had been determined from each school, namely 70. The level of completeness of students' critical thinking skills throughout the district of Labuhanbatu Utara there are 164 students complete with $62.12 \%$ which are in the good category and 100 students are not complete with $37.88 \%$ which are in the bad category.

The percentage of completeness of students' critical thinking skills in SMAN 1 Kualuh Selatan was 30 students 
complete with $81.08 \%$ which was very good category and 7 students were not complete with $18.92 \%$ which was very poor category. In SMAN 1 AekNatas, 33 students completed with $84.62 \%$ which included in the excellent category and 6 students were not completed with $15.38 \%$ which included in the very poor category. In SMP Negeri 1 KualuhLeidong, 21 students completed with 61.76\% which included good category and 13 students did not complete with $38.24 \%$ which included in the unfavorable category. In SMAN 1 KualuhHilir, 21 students completed with 55.26\% which was categorized quite good and 17 students did not complete with $44.74 \%$ which was categorized quite good. In SMAS K. Londut were 21 students completed with $58.33 \%$ which was categorized as good enough and 15 students were not complete with $41.67 \%$ which included in the category quite well. In SMAS Muhammadiyah 9 AekKanopan as many as 24 students completed with $66.67 \%$ which included good categories and 12 students did not complete with $33.33 \%$ which included in the unfavorable category. In SMA D.I. Panjaitan as many as 4 students completed with $19.05 \%$ which included very poor categories and 17 students were not completed with $80.95 \%$ which included in the excellent category. While in SMAS PelitaAekKanopan, 10 students completed with $43.48 \%$ which included in the good enough category and 13 students did not complete with 56.52\% which included in the good enough category.

One of the factors that causes empowerment of thinking skills is not developed in the biology learning process so far because the biology curriculum that is designed demands a wide range of target material so that the teacher is more focused on how to complete the material and also the lack of teacher's understanding of learning strategies that can promote students' thinking skills. In addition, the teacher's lack of understanding of thinking skills causes a tendency not to teach or assess students' thinking skills. In biology learning, when students make observations, students need to build an understanding of the observed phenomena, here it clearly involves the processes and thinking skills for problem solving and decision making, so that observation activities are not only limited to observing natural phenomena but can develop reasoning abilities, problem solving and drawing conclusions [22].

According to Sagala (in [23]) in the learning process must be built atmosphere of dialogue and continuous question and answer directed to improvement and improvement of students 'thinking skills. Students' critical thinking abilities will develop if supported by the efforts undertaken by the teacher in the activities expected core. The teacher tries to improve the ability to think critically by giving different opinions, sometimes the teacher makes songs related to the material so that students are more happy and enthusiastic in following the learning process, do question and answer with students so that students are active in the learning process and train students to dare to express their opinions, provide learning with a good atmosphere, and efforts to discuss the answers of friends so that students can exchange ideas and communicate with friends so that a lot of information is obtained by students.
Learning biology contextually is an approach that directs student learning so that it can construct knowledge gained from problems or real life. Learning by formulating problems, finding solutions, finding facts and concluding problems, here is needed creative thinking skills that generate new ideas as problem solving. Therefore, contextual learning is one that is very necessary to be applied in a learning in school to build students' critical thinking skills.

\section{CONCLUSION}

Based on the results of the research and discussion, the following conclusions can be obtained:

1. The level of students' critical thinking skills in Class XII of Senior High Schools in Labuhanbatu Utara Regency was 70.25 which has been included in the medium criteria.

2. The level of students' critical thinking skills in Class XII of Senior High Schools in Labuhanbatu Utara Regency based on the location of schools in the urban areas was 73.16 which has been included in the high criteria. While the location of schools in the suburban areas was 66.53 which has been included in the medium criteria.

3. The level of students' critical thinking skills in Class XII of Senior High Schools in Labuhanbatu Utara Regency based on gender in male was 71.13 which has been included in the high criteria. While for female was 69.41 which has been included in the medium criteria.

4. The level of students' critical thinking skills in Class XII of Senior High Schools in Labuhanbatu UtaraRegency based on indicator 4.1 was 75.08, indicator 5.1 was 73.94, indicator 4.2 was 72.49 , indicator 2.2 was 71.46 , and indicator 2.1 was 71.22 including high criteria. While indicator 3.1 was 70.58 , indicator 3.2 was 67.12 , indicator 5.2 was 65.79 , indicator 1.2 was 64.46 , and indicator 1.1 was 61.58 including the medium criteria.

5. Completeness of students' critical thinking skillsin Class XII of Senior High Schools in Labuhanbatu Utara Regency, there were 164 students completed $62.12 \%$ with good category and 100 students did not complete $37.88 \%$ in the unfavorable category.

\section{REFERENCES}

[1] Afcariono, M. 2008. Penerapan Model Pembelajaran Berbasis Masalah untuk Meningkatkan Kemampuan Berpikir Kritis Siswa pada Mata Pelajaran Biologi. Jurnal Pendidikan Inovatif, 3(2): 65-68.

[2] Trianto. 2007. Mendesain Model Pembelajaran Inovatif-Progresif. Jakarta: Kencana Prenada Media Group.

[3] Ariyati, E. 2010. Pembelajaran Berbasis Praktikum dengan Memanfaatkan Hutan Mangrove untuk Mengembangkan Kemampuan Berpikir Kritis dan Sikap Ilmiah Mahasiswa. Tesis Pendidikan IPA. Bandung: Universitas Pendidikan Indonesia.

[4] Atkinson, L. Smith, E., Bem, D. 2007. Pengantar Psikologis Edisi Kesebelas Jilid Satu. Harcourt Brace Company: Interaksara.

[5] Santrock, J.W. 2010. Psikologi Pendidikan. Jakarta: Salemba Humanika.

[6] Achmad, A. 2007. Memahami Berpikir Kritis. Dari http://researchengines.com /1007arief3.html. Diakses: 04 Desember 2016.

[7] Watson, G., Glaser, E. M. 2008. Critical Thinking Appraisal. New York: Harcourt Brace Jovanovich, Inc.. 
[8] Priyono, W. 2014. Contoh Lembar Penilaian Kemampuan Berpikir Kritis (KBK) oleh Siswa. http://wahidbiyobe.blogspot.co.id/2014/05/contoh-lembar-penilaiankemampuan.html. Diakses: 06 Maret 2017.

[9] Anderson, L.W., dan Krathwohl, D.R. 2010. Kerangka Landasan untuk Pembelajaran, Pengajaran dan Asesmen (Revisi Taksonomi Pendidikan Bloom). Yogyakarta: Pustaka Pelajar.

[10] Brickman, P., C. Gormally, N. Armstrong, B. Hallar. 2009. Effects of Inquiry-Based Learning on Students' Science Literacy Skills and Confidence. International Journal for the Scholarship of Teaching and Learning, 3(2): 1-22.

[11] Indarti, M., Soekamto, H., dan Soelistijo, D. 2013. Pengaruh Penerapan Model Pembelajaran Group Investigation Terhadap Kemampuan Berpikir Kritis Siswa SMA. Skripsi. Malang: Universitas Negeri Malang.

[12] Arisah, H. 2014. Analisis Kesulitan Belajar pada Materi Pokok Bioteknologi di SMA Kelas XII Se-Kecamatan Labuhan Deli Medan Tahun Pembelajaran 2013/2014.Tesis. Medan: Program Pascasarjana Universitas Negeri Medan.

[13] Yaumi, Muhammad. 2012. Pembelajaran Berbasis Multiple Intelligences. Jakarta: Dian Rakyat.

[14] Sophian, H. 2013. Deskripsi Kemampuan Berpikir Logis dan Pemahaman Konsep Sistem Hormon pada Kelas XII SMA. Solo: Makalah Disajikan dalam Seminar Nasional XII Pendidikan Biologi Fakultas Keguruan Ilmu Pendidikan Universitas Negeri Surakarta.

[15] Hassoubah, I., Z. 2004. Developing Creative and Critical Thinking Skill (Cara Berpikir Kreatif dan Kritis). Bandung: Nuansa.

[16] Yustyan, S., Widodo, N., dan Pantiwati, Y. 2015. Peningkatan Kemampuan Berpikir Kritis dengan Pembelajaran Berbasis Scientific Approach Siswa Kelas X SMA Panjura Malang, Jurnal Pendidikan Biologi Indonesia, 1(2): 240-254.

[17] Tilaar, M., Paat, Jimmy., dan Paat, Lody. 2011. Pedagogik Kritis. Jakarta: Rineka Cipta.

[18] Arends, R.I. 2012. Learning to Teach Ninth Edition. New York: The McGraw-Hill Companies, Inc.

[19] Wasonowati, Tri redjeki, Sri Retno Dwi Ariani. 2014. Penerapan Model Problem Based Learning pada Pembelajaran Hukum-hukum Dasar kimia ditinjau dari Aktivitas dan Hasil Belajar siswa Kelas X IPA SMA Negeri 2 Surakarta Tahun Pelajaran 2013/2014. Jurnal Pendidikan Kimia. Volume 3.

[20] Harms, U. 2002. Biotechnology Education in School. Electronic Journal of Biotechnology, 5(3): 1-11.

[21] Zain, N. 2014. Pengaruh Strategi Pembelajaran Aktif (Active Learning) Terhadap Kemampuan Bertanya, Berpikir Kritis dan Hasil Belajar Siswa Tentang Bioteknologi di SMP Negeri 7 Medan.Tesis(tidak diterbitkan).Medan: Pascasarjana Universitas Negeri Medan.

[22] Listiana, L. 2013. Pemberdayaan Keterampilan Berpikir dalam Pembelajaran Biologi Melalui Model Kooperatif Tipe GI (Group Investigation) dan TTW (Think, Talk, Write). Seminar Nasional X Pendidikan Biologi FKIP Universitas Negeri Solo, 1-9.

[23] Iskandar. 2009. Psikologi Pendidikan (Sebuah Orientasi Baru). Ciputat: Gaung Persada. 